УДК 340.12

DOI https://doi.org/10.32837/apdp.v0i86.2430

П. Б. Пилипищин

\title{
ФІЛОСОФСЬКО-ПРАВОВИЙ ПОГЛЯД НА ТРАНСФОРМАЦІЮ ІДЕЙ ІНДИВІДУАЛІЗМУ У ПРОТЕСТАНТИЗМІ
}

Постановка проблеми. Найбільш важливими і показовими для осмислення сутності Реформації є питання теологічні, оскільки саме вони стали тим фундаментом, на якому базується філософсько-правова концепція індивідуалізму. До цих питань належить питання про структуру церковної організації, яке, у свою чергу, призвело до питання рівності між мирянами та священнослужителями, а згодом і між всіма людьми як дітьми Божими; розуміння покликання, з яких частково зросла трудова етика протестантських країн; вчення про два царства спроба обгрунтувати розмежування компетенції матеріальної і духовної складових частин людського буття.

У статті робиться спроба проаналізувати всі вищенаведені причини, які стали основою для формування нового типу людини - індивідуаліста - як результату світоглядно-правової трансформації.

Аналіз останніх досліджень і публікацій. Питання значення людини, її внутрішнього світу в період Реформації були розкриті такими науковцями: О.В. Грищук, Ю.М. Вільчинським, О.С. Ігнатьєвою, О.М. Корх, Т.Б. Коваль, Т.М. Кучерою, О.М. Омельчук, А.В. Петрихин, Л.С. Соловйовою, А.В. Скоробогатовим, 3.В. Шевченко й ін. Водночас їх науковий аналіз не стосувався розкриття індивідуалізму через аналіз протестантизму як течії, яка не лише здійснила реформу в релігійному світі, але й кардинально поміняла свідомість та мислення тогочасної людини, перетворивши іï на індивідуаліста.

Мета статті полягає в розкритті протестантизму як історичного вчення, завдяки якому виник новий світогляд, а отже, і новий тип людини - індивідуаліст.

Основний матеріал дослідження. Свропейська Реформація XVI ст. не була подією, що мала суто релігійне значення, адже вона стала причиною конфесіоналізації Німеччини, визначила політичний, правовий і культурний вигляд протестантських країн, загалом вплинула на розвиток філософської та соціальної думки. Філософія права епохи Реформації здійснила спробу очистити від схоластичних деформацій античну філософію, зробила більш доступним її істинний зміст, стала реакцією на однозначний теоцентризм, обстоювала ідею особистої відповідальності людини за свою поведінку перед Богом. Відкинувши повністю посередництво церкви, реформатори поєднали сильний влив релігії з гуманізмом Відродження, який обстоював цінність, винятковість та самостійність людини [1, с. 370].

Ю.І. Рубинский відзначає особливу роль епохи Реформації у формуванні саме ліберального індивідуалізму, який передбачає почуття власної гідності, незалежність від будь-чиїх милостей, до особистої відповідальності за свої вчинки, готовність до ризику тощо [2]. Такої ж думки й O.M. Корх, який уважає, що «цінності протестантизму стали моделлю ліберально-демократичного суспільного устрою

(C) П. Б. Пилипишин, 2020 
багатьом західним країнам і безпосередньо ініціювали фундаментальну ідею принципової рівності всіх і кожного не тільки перед Божими, але і мирськими законами» [3, с. 70-71]. Ці науковці, як і багато інших, роблять подібні висновки, оскільки в Реформації центральним питанням було питання про людину, що крізь призму теоцентризму поставало як питання про її спасіння [4, с. 209].

Як уважає А.В. Скоробагатов, позитивне значення Реформації полягає в такому: формування державного суверенітету; принцип віротерпимості; конфіскація церковного майна; обмеження значення церкви; скасування канонічного права (у багатьох країнах скасована церковна юрисдикція) [5, с. 51-52].

Реформатори проголосили найвищим критерієм особистий релігійний досвід віруючого, відмовившись від церковного авторитету у тлумаченні Біблії. Вони залишили тільки Святе Письмо, з якого кожен міг безпосередньо черпати знання про Бога, прагнучи знищити будь-яке посередництво між Богом і людиною. Протестантизм звів вуранг обов'язкового релігійного припису читання Біблії і самостійний роздум над нею, як і бесіди пастора з парафіянами на біблійні теми. Це, безсумнівно, вимагало певного рівня освіти і виробляло звичку до самостійного мислення. Усе це сприяло зростанню культурно-освітнього рівня віруючих, що, у свою чергу, створювало шар грамотних і кваліфікованих робочих рук, затребуваних на нових видах виробництва. Ці обставини підвищували, у свою чергу, економічний рівень життя [6, с. 366-367]. На глибоке зауваження Г.В.Ф. Гегеля, те, що Реформація та «сама Біблія стала основою християнської церкви, надзвичайно важливо: тепер кожен повинен сам вчитися по ній; кожен повинен мати можливість, керуючись нею, визначати свою совість. Це величезна принципова зміна: уся традиція і вся церковна система стають проблематичними, і принцип авторитету церкви відкидається < ...> Завдяки запереченню авторитету церкви поділ став необхідний» [7, с. 390].

Філософії досліджуваної доби властива орієнтація людини на роботу над своїм внутрішнім світом, на формування його єдності, боротьбу з афектами, внесення у свідомість дисципліни, самоконтролю та відповідальності, оскільки в них визнавались основні причини того, що відбувається. 3 позицій раціоналізму було переглянуто і саме уявлення про віру в Бога, що увійшло в мислення науковців і втілилось у принципі: «піддавай усе сумніву». Протестантська ідеологія запропонувала прагматизм як ще одну рису стилю мислення того часу: в епоху Реформації люди розглядали світ через існування порядку речей, де все влаштоване за відповідними правилами, законами; ці закони слід пізнавати, жити відповідно до них, отже, бути відповідальним [8, с. 119].

Найголовнішим для нашого дослідження є те, що протестантизм приділяв основну увагу індивідуальній відповідальності перед Богом за власний порятунок. У віровченні протестантизму відповідальність людини базувалась на принципах:

1) «виправдання вірою». Суть даного принципу зводиться до спасіння людини, яке залежить від віри у спокутну жертву Христа;

2) «абсолютного визначення наперед». Цей принцип означає, що ще до створення світу Бог вирішив питання про спасіння кожної людини, богообраність якої виявляється в побожності, доброчесності, успішній діяльності, покірності тощо; 
3) «загального священства», згідно з яким кожний хрещений християнин є вибраним, отримує посвячення на надприродне спілкування з Богом, право без посередництва церкви проповідувати і здійснювати богослужіння, через це виявляти свою відповідальність.

Останній принцип свідчить про те, що головною філософсько-правовою ідеєю Реформації є особиста відповідальність людини перед Богом, без посередництва церкви [9].

Розвиток філософії і права в добу Реформації був зумовлений необхідністю формування нового типу людини, яка створює себе сама, відповідальна насамперед перед собою та шукає опору й обгрунтування своєї поведінки в самій собі. У період Реформації відповідальність людини була зумовлена самооцінкою приниження: «не я, але Бог у мені», що передбачало цілковиту залежність від Творця, який встановив людську систему загальної корисності. Перетворення людини на корисну для ближнього річ трактувалося як богоугодна справа, а теологічний постулат любові до ближнього перетворився на «службу ближньому» [10, с. 75]. Реформаційне вчення було спрямоване на відновлення у споконвічній чистоті християнської релігійності. Така ознака була властива всім напрямам реформаційного віровчення; він міститься в інституційних механізмах здійснення Реформації. Суть бажаного правопорядку полягала в особливій моделі співвідношення індивіда і колективу, де людина повинна обов'язково, жорстко підпорядковуватись громаді [5, с. 50-51]. Реформація також посприяла появі незалежного, самостійного, відповідального у своїх судженнях і вчинках індивіда з волею морального вибору. Протестантські ідеї стали каталізаторами для кристалізації нового типу особистості, з новою культурою і ставленням до світу. Суть нової ідеї, запропонованої Реформацією, полягала в тому, що поняттям “Вeruf” (справа, покликання, професія) закладалася оцінка, згідно з якою виконання обов'язку в рамках мирської професії розглядається як найвище завдання морального життя людини. Уперше таку трансформацію зауважив європейський мислитель Г.В.Ф. Гегель. У його творчості містяться вказівки на те, що коріння нової раціональності, нової самосвідомості, нового ставлення до праці і збагачення, що відрізняють Західну Європу XVIII-XIX ст., треба шукати в реформаційному процесі. Згодом до такої думки схилялись і К. Маркс та Ф. Енгельс, а потім і Макс Вебер [11, с. 49].

Отже, до головних засад протестантизму варто віднести такі положення: закріплення за індивідом права на особисте спілкування з Богом; визнання основним джерелом пізнання людиною Бога та моральних і релігійних принципів - Святе Письмо (Біблія); віра у рятівну жертву Ісуса Христа; заперечення таких джерел віри, як Священний Переказ - папських булл (декрети), енциклік (послання); заперечення посередницьких відносин між Богом, індивідом та церквою, священства; визнання визначеності людської долі (здобути чи втратити можливість спасіння); спрощення культової діяльності [12, с. 91-92].

У літературі віднаходимо ще ознаки, які підкреслюють суть протестантизму. По-перше, усе створене людьми (Святе Передання - вчення отців Церкви) є істинним тільки тією мірою, якою відповідає Писанню, а тому християнські догмати можна критикувати і змінювати. По-друге, кожна людина має право по-своєму 
розуміти Святе Письмо. По-третє, порятунок досягається тільки через особисту віру в Бога, не за допомогою молитов, обрядів. По-четверте, між Богом і людьми не може бути жодних посередників. По-четверте, оскільки кожен має право тлумачити Біблію по-своєму, протестантизм виявляється розколотим на безліч течій і сект. По-п'яте, віра, суто духовне спілкування людини з Богом протиставляється зовнішнім формам релігії [13, с. 18-19].

Отже, Реформацію дослідники пов'язують із формуванням і затвердженням християнської свободи, індивідуалізму, особистої совісті, критичного приватного судження. Завдяки Реформації відбулась зміна формування мислення, в основі якого лежить усвідомлення сокровенності реальності, індивідуальне судження. Реформаційне філософсько-правове вчення зробило акцент на внутрішній значущості ідей і особистості як суб'єкті, а не на їхньому об'єктивному сенсі шляхом затвердження виправдання і спасіння душі через особисту віру у Христа [14, с. 76]. Соціокультурна ситуація епохи Реформації продовжила формувати новий тип людини індивідуаліста, який шукає опору й обгрунтування своєї поведінки в самому собі. Реформація змінила спрямованість права від теологічного і корпоративного підходу права до його доктринально-теоретичного розуміння, сформулювала новий юридичний світогляд із першим масовим проривом до правосвідомості. Свобода віри, яка була декларована реформаторами, стала каталізатором появи нових принципів інтелектуальної і моральної свободи людини на нових моральних і соціальних орієнтирах. Також до основних реформаторських філософсько-правових ідей відносять: проголошення нового ставлення Бога до кожної людини - особисте; рівність між священнослужителями та мирянами, шанс на індивідуальні пошуки віри, священність усіх віруючих. Було проголошено невідчуженість прав і свобод людини, які сприймалися через антиавторитарний релігійний рух, а не крізь призму античної римської правової традиції чи ідеологію «хартій і вольностей» $[1$, с. $362-363]$.

У реалізації індивідуалістичної концепції суспільства і моралі людини саме протестантизм і Реформація відіграли вирішальну роль. Філософсько-правові погляди протестантської Реформації сприяли появі автономного, самостійного, ініціативного, відповідального за свої вчинки індивіда зі свободою самовизначення. Нові цінності протестантської філософії права (ведення комерційної діяльності, позитивне ставлення до праці, раціональна організації роботи, максимізації прибутку) заклали підгрунтя для духовної основи нового типу працівника і культури праці як сумлінного та відповідального індивіда, сформували новий індивідуалізму на Заході. Реформація заклала духовні основи індивіда з бажанням сумлінного виконання роботи як вищого самообов'язку, без якого неможливе високоефективне виробництво. Самостійність у рішеннях, прагнення до матеріального благополуччя, відданість Богу стають моральними критеріями. Невпинна діяльність в рамках своєї професії - це новий тип розуміння того, що це є найкращим засобом спокути гріхів і отримання внутрішньої впевненості у спасіння душі. Праця, яка викорінює будь-які сумніви релігійного характеру і надає людині впевненості в обраності, стала наслідком реформації релігії [14, с. 75$]$. 
Висновки. Епоха Реформації здійснила переворот у християнському світі, змінила весь тогочасний світогляд, адже основні зміни, які були причетні до теологічного простору, спричинили зміни у внутрішньому світі кожної людини і суспільства загалом. Спробуємо простежити таку трансформацію: 3 теологічних змін на світоглядно-правові.

По-перше, реформатори обстоювали скасування будь-якого посередництва між Богом та людиною. Така теологічна зміна спричинила зміну в соціально-правовому просторі. Ідеться про проголошення рівності між людьми, зокрема й між мирянами та духовенством.

По-друге, ідеологією індивідуалізму з'явився протестантизм - лютеранство, кальвінізм, англіканство. Завдяки цим ідеологіям на перший план були висунуті відносини людини з Богом, а не із церквою як інститутом.

По-третє, протестанти обстоювали можливість самостійного читання та тлумачення Біблії. Така суто теологічна зміна трансформувалася у філософсько-правову, оскільки виробила в людині звичку до самостійного, критичного мислення (права на критичне приватне судження).

По-четверте, свобода віри як теологічна зміна вплинула на затвердження християнської свободи, а згодом привела до появи морального вибору та самостійності у своїх судженнях і вчинках, тобто свободи самовизначення.

По-п'яте, біблійний прагматизм (світ - це певний порядок речей), затверджений реформаторами, виховав людину з моральним обов'язком дотримуватись правил та законів світу, а отже, і законів людських - позитивного права.

По-шосте, запропонована теологічна ідея особистої відповідальності перед Богом стала філософсько-правовою ідеєю відповідальності за свою поведінку та сприяла пошуку обгрунтування цієї поведінки людиною.

По-сьоме, теологічна орієнтація протестантів на внутрішній світ людини зорієнтувала людину на роботу над собою, вивченням афектів, власного досвіду і не лише релігійного, а в результаті - до особистого самоконтролю.

По-восьме, орієнтація протестантизму на трудову діяльність, професійні досягнення людини як на покликання дали поштовх до розвитку інтелектуальної свободи, яка передбачала логічність та послідовність дій, перевагу розумових процесів над ірраціональними.

\section{Jimepamypa}

1. Омельчук О.М. Розвиток уявлень про поведінку людини у філософії права епохи Реформації. Університетські наукові записки. 2011. № 3. С. 362-370.

2. Рубинский Ю.И. Европейские ценности. Доклады Института Европы Российской академии наук. Москва : Институт Европы РАH ; Рус. сувенир, 2007. № 189. URL: https:// magazines.gorky.media/vestnik/2009/26/evropejskie-czennosti.html.

3. Корх О.М. Проблема індивідуалізму (історико-філософський аналіз) : дис. ... докт. філос. наук: 09.00.05. Дніпропетровськ, 2002.397 с.

4. Грищук О.В. Філософія конституційних цінностей : монографія. Київ : Компанія «BAITE». 2019. $416 \mathrm{c}$.

5. Скоробогатов А.В. История политических и правовых учений : учебно-методическое пособие. Казань : Таглимат, 2004. $209 \mathrm{c.}$

6. Коваль Т.Б. Личность и собственность в христианстве: Православие. Католицизм. Протестантизм. Сравнительный анализ : дис. ... докт. истор. наук: 07.00.03. Москва, 2009. 490 с. 
7. Гегель Г.В.Ф. Философия истории. Перевод А.М. Водена. Москва,1935. 470 с.

8. Братасюк В.М. Інтелектуальний консенсус епохи і розвиток правового мислення. Проблели філософї права. 2003. Т. 1. С. 116-121.

9. Ігнатьєва О.С. Віросповідна сутність протестантизму як предмет релігієзнавчого дослідження. Вісник Черкаського університету. Серія «Філософія». Вип. 154 C. 110-117. URL: http://www.nbuv. gov.ua/portal/Soc_Gum/Vchu/N154/N154p110-117.pdf.

10. Петрук В.М.М. Соціокультурні засади легітимації самовизначення соціального суб’єкта. Гуманітарний часопис. 2009. № 3. С. 74-78.

11. Реформация в контексте истории европейской цивилизации. Сибирь на перекрестье мировых религий : материалы Третьей межрегиональной конференции. Новосибирск, 2006. С. 27-53.

12. Вільчинський Ю.М., Кучера Т.М. Філософія епохи Відродження та Реформації. Філософія : навчальний посібник / Ю.М. Вільчинський (керівник авт. кол.) та ін. ; М-во освіти і науки України, ДВНЗ «Київ. нац. екон. ун-т ім. Вадима Гетьмана». Електрон. текстові дані. Київ : КНЕУ, 2019. С. $75-92$.

13. Философия эпохи Возрождения : методическое пособие / под ред. Г.Л. Микиртичан. Санкт-Петербург, 2007.60 с.

14. Войтенко В.П. Индивидуализм в России и на Западе: сравнительный концептуальный анализ : дис. ... канд. филос. наук: 09.00.11. Ростов-на-Дону, 2014. 176 с.

\section{Анотація}

Пилипищин П. Б. Філософсько-правовий погляд на трансформацію ідей індивідуалізму у протестантизмі. - Стаття.

У статті робиться спроба розкриття індивідуалізму через аналіз протестантизму як течії, яка не лише здійснила реформу в релігійному світі, але й кардинально поміняла свідомість та мислення тогочасної людини, перетворила їі на індивідуаліста. Теологічна проблематика стала фундаментом, на якому базувалась тогочасна філософсько-правова концепція індивідуалізму. До цих питань належать питання: про структуру церковної організації, питання рівності між мирянами та священнослужителями, а згодом між всіма людьми як дітьми Божими; розуміння покликання, з якого частково зросла трудова етика протестантських країн; вчення про два царства - спроба обгрунтувати розмежування компетенції матеріальної і духовної складових частин людського буття.

Доведено, що завдяки Реформації відбулась зміна формування мислення, в основі якого лежить усвідомлення сокровенності реальності, індивідуальне судження. Філософії досліджуваної доби властива орієнтація людини на роботу над своїм внутрішнім світом, на формування його єдності, боротьбу з афектами, внесення у свідомість дисципліни, самоконтролю та відповідальності, оскільки в них визнавались основні причини того, що відбувається. Обгрунтовано, що Реформація посприяла появі незалежного, самостійного, відповідального у своїх судженнях і вчинках індивіда з волею морального вибору.

Визначено, що епоха Реформації здійснила переворот у християнському світі, змінила весь тогочасний світогляд, адже основні зміни, які стосувалися теологічного простору, спричинили зміни у внутрішньому світі кожної людини і суспільства загалом. Така трансформація спочатку відбувалась у теологічному світі, а згодом перейшла і на світогляд людини і суспільства загалом. До теологічних змін, які згодом стали світоглядно-правовими, запропоновано віднести: обстоювання реформаторами скасування будь-якого посередництва між Богом та людиною; розвиток таких ідеологій, як: лютеранство, кальвінізм, англіканство; можливість самостійного читання та тлумачення Біблії; зміну суті свободи віри; біблійний прагматизм; теологічну ідею особистої відповідальності перед Богом; теологічну орієнтацію протестантів на внутрішній світ людини; орієнтацію протестантизму на трудову діяльність, професійні досягнення людини як на покликання.

Ключові слова: протестантизм, Реформація, свобода, індивідуалізм, індивідуаліст, світогляд, свідомість, відповідальність. 


\section{Summary}

Pylypyshun P. B. Philosophical and legal view on the transformation of ideas of individualism in Protestantism. - Article.

The article is devoted to making an attempt to reveal individualism through analysis of Protestantism as a trend which not only reformed religious world, but also fundamentally changed the consciousness and mentality of then person, transforming him into individualist. Theological issues became the foundation on which the philosophical and legal concept of individualism was based. These issues include: the structure of the church organization, which led to the issue of equality between the laity and the clergy, and later between all people as children of God; understanding of the vocations from which the work ethic of Protestant countries has partly grown; the doctrine of the two kingdoms is an attempt to justify the delimitation of the competence of the material and spiritual components of human existence.

It was proven that because of Reformation there had been a change in shaping of thinking based on understanding of reality secrecy and individual judgment. The philosophy of investigated century is characterized by person's focus on work on his inner world, on his unity formation, on struggle against affects, introducing to human consciousness discipline, self-control and responsibility, since they were recognized as main reasons of what was going on. It is substantiated that Reformation stimulated the emergence of independent, self-sufficient, responsible in his judgments and actions individual with moral choice will.

It was determined that Reformation age, having made the revolution in Christian world, had changed the whole then worldview, since basic modifications concerning theological space had led to changes in inner world of each person and society, in particular. Initially, such a transformation took place in theological world and then influenced on the worldview of a person and society in general. It is proposed to refer to theological changes, which later became worldview and legal: advocacy of cancellation of any mediation between God and person by reformers; development of such ideologies as: Lutheranism, Calvinism, Anglicanism; possibility of independent Bible reading and interpreting; change the substance of faith freedom; biblical pragmatism; theological conception of personal responsibility to God; theological focus of protestants on inner world of a person; Protestantism orientation towards labour activity, professional achievements of a person as to his mission.

Key words: Protestantism, Reformation, freedom, individualism, individualist, worldview, consciousness, responsibility. 